\title{
Preparation of porous apatite granules from calcium phosphate cement
}

\author{
A. C. Tas
}

Received: 30 March 2007/Accepted: 6 November 2007/Published online: 1 December 2007

(c) Springer Science+Business Media, LLC 2007

\begin{abstract}
A versatile method for preparing spherical, micro- and macroporous (micro: 2-10 and macro: 150$550 \mu \mathrm{m}$ pores), carbonated apatitic calcium phosphate (Ap-CaP) granules (2-4 mm in size) was developed by using $\mathrm{NaCl}$ crystals as the porogen. The entire granule production was performed between 21 and $37{ }^{\circ} \mathrm{C}$. A CaP cement powder, comprising $\alpha-\mathrm{Ca}_{3}\left(\mathrm{PO}_{4}\right)_{2}(61 \mathrm{wt} . \%)$, $\mathrm{CaH}-$ $\mathrm{PO}_{4}(26 \%), \mathrm{CaCO}_{3}(10 \%)$ and precipitated hydroxyapatite, $\mathrm{Ca}_{10}\left(\mathrm{PO}_{4}\right)_{6}(\mathrm{OH})_{2}(3 \%)$, was dry mixed with $\mathrm{NaCl}$ crystals varying in size from $420 \mu \mathrm{m}$ to $1 \mathrm{~mm}$. Cement powder (35 wt.\%) and $\mathrm{NaCl}(65$ wt.\%) mixture was kneaded with an ethanol- $\mathrm{Na}_{2} \mathrm{HPO}_{4}$ initiator solution, and the formed dough was immediately agitated on an automatic sieve shaker for a few minutes to produce the spherical granules. Embedded $\mathrm{NaCl}$ crystals were then leached out of the granules by soaking them in deionized water. $\mathrm{CaP}$ granules were micro- and macroporous with a total porosity of $50 \%$ or more. Granules were composed of carbonated, poorly crystallized, apatitic $\mathrm{CaP}$ phase. These were the first spherical and porous $\mathrm{CaP}$ granules ever produced from a self-setting calcium phosphate cement. The granules reached their final handling strength at the ambient temperature through the cement setting reaction, without having a need for sintering.
\end{abstract}

Certain commercial equipment, instruments or materials are identified in this paper to foster understanding. Such identification does not imply recommendation or endorsement by the author, nor does it imply that the equipment or materials identified are necessarily the best available for the purpose.

A. C. Tas $(\bowtie)$

Department of Biomedical Engineering, Yeditepe University, Istanbul 34755, Turkey

e-mail: actas@yeditepe.edu.tr

\section{Introduction}

Synthetic calcium phosphate $(\mathrm{CaP})$-based skeletal repair or hard tissue regeneration materials in the form of granules of well-defined geometry, preferably in the shape of spheres with variable diametrical production sizes, can provide the orthopedic or periodontal surgeon with an ease in filling the bone defects/voids of irregular and patientspecific shapes. In comparison, sintered and pre-shaped $\mathrm{CaP}$ prismatic blocks can be difficult to fill voids of irregular dimensions. Sintered $\mathrm{CaP}$ bioceramic blocks typically comprise of pure calcium hydroxyapatite (HA: $\left.\mathrm{Ca}_{10}\left(\mathrm{PO}_{4}\right)_{6}(\mathrm{OH})_{2}\right)$, pure $\beta$-tricalcium phosphate $(\beta$-TCP: $\left.\beta-\mathrm{Ca}_{3}\left(\mathrm{PO}_{4}\right)_{2}\right)$ or the biphasic mixtures (HA-TCP) of the two [1-3]. It shall be remembered that sintered, wellcrystallized HA, TCP, and biphasic HA-TCP are good platforms for osteoconduction.

An overwhelming majority of the early examples of $\mathrm{CaP}$ granule synthesis routines involved a high-temperature sintering step, which resulted in the production of wellcrystallized $\mathrm{CaP}$ granules [4-12]. High-temperature sintering as a means of production was again quite popular in the later examples of $\mathrm{CaP}$ granule manufacturing. An abridged version of the literature survey is given below. Fabbri et al. [13] formed millimeter-sized HA granules by first dripping a CaP-containing aqueous suspension into liquid nitrogen, followed by sintering the formed beads, which were devoid of any significant macroporosity. Apatitic granules of coralline-origin were prepared and tested in vivo by Holtgrave and Donath [14] and Baran et al. [15]. Luo and Nieh [16] and Kawai et al. [17] used the spray granulation process to produce only micron-sized $\mathrm{CaP}$ granules, which were too small to be handled by the orthopedic or periodontal surgeons. However, this technique also necessitated a follow-up sintering step. Liu [18] 
modified the dripping procedure originally developed by Fabbri et al. [13], and added polyvinylbutyrale (PVB) into the ceramic suspensions. Granules were then sintered at $1,200{ }^{\circ} \mathrm{C}$ to strengthen the wet granules, as well as to burn off of the polymer, PVB. Well-crystallized CaP granules synthesized by Liu [18] had porosity from 24 to $75 \mathrm{vol} \%$, pore sizes from 100 to $400 \mu \mathrm{m}$, and granular sizes from 0.7 to $4 \mathrm{~mm}$. The use of PVB, as the porogen, was also tested by Zyman et al. [19] in forming porous granules. The complete burn off of PVB always necessitated high temperatures $\left(<1,150{ }^{\circ} \mathrm{C}\right)$. Maruyama and Ito [20] formed a paste consisting of HA powders, $\mathrm{CaO}, \mathrm{ZnO}$, chitosan and malic acid, and wet granules were first formed out of this paste, followed by sintering at $1,150{ }^{\circ} \mathrm{C}$. Gauthier et al. [21] hydrolyzed brushite $\left(\mathrm{CaHPO}_{4} \cdot 2 \mathrm{H}_{2} \mathrm{O}\right)$ powder in a basic $\mathrm{NaOH}$ solution to obtain apatitic calcium phosphate (Ap-CaP) powders and sieved the water-soaked Ap-CaP powders to form granules in the size range of 200-500 $\mu \mathrm{m}$. However, these soft granules were then heated over the temperature range of $550-950{ }^{\circ} \mathrm{C}$. Oonishi et al. [1, 22] tested the in vivo response of granules of sintered hydroxyapatite. Granules obtained by Oonishi et al. [1, 22] were produced by simply sieving (to $100-300 \mu \mathrm{m}$ size range) the finely ground chunks of previously sintered hydroxyapatite ceramics. Merkx et al. [23] examined the porous (trabecular) bovine apatite granules in an in vivo goat model. Paul and Sharma [24] first prepared the HA powders by reacting $\mathrm{Ca}(\mathrm{OH})_{2}$ with $\mathrm{H}_{3} \mathrm{PO}_{4}$, then formed viscous aqueous suspensions in the presence of chitosan and paraffin, and obtained granules upon stirring those thick suspensions. Formed granules were fired at $1,100{ }^{\circ} \mathrm{C}$ to achieve the strength required for handling. Patel et al. [25] used a somewhat similar procedure, to that used by Paul and Sharma [24], to produce Si-substituted apatite granules and tested their in vivo behavior. The clinical study of Schwartz et al. [26] employed 55\%HA-45\% TCP biphasic, macroporous and well-crystallized, sintered (at $1,200{ }^{\circ} \mathrm{C}$ ) granules with sizes varying from 2 to $3 \mathrm{~mm}$ in vivo resorbability of the sintered but macroporous granules of excellent pore connectivity was found to be quite poor even after a follow-up period of 36 months [26]. A similar high-temperature process for granule production was reported by Tanaka et al. [27], as well. In a quite different approach to form spherical $\mathrm{CaP}$ granules, Barinov and coworkers [28, 29] first prepared an aqueous suspension by using precipitated $\mathrm{CaP}$ powders, and then mixed it with a $10 \%$ gelatin solution. Upon stirring this $\mathrm{CaP}-$ gelatin suspension into a bath of vegetable oil, spherical granules of micron size were formed. Wet granular aggregates were then collected and sintered at $1,200{ }^{\circ} \mathrm{C}$ to provide those with the necessary handling strength. Rodriguez-Lorenzo et al. [30] prepared apatite suspensions containing soluble starch, and utilized the swelling of starch to form pores, followed by sintering at $1,100{ }^{\circ} \mathrm{C}$ and granulation. In brief, research related to the production of calcium phosphate granules is gaining pace in recent years [31-39].

Pore sizes in human cortical bones are known to range from 1 to $100 \mu \mathrm{m}$, whereas in trabecular bones the pores were varying from 200 to $700 \mu \mathrm{m}$ [2]. The use of $\mathrm{NaCl}$ as the porogen to achieve such significant pore sizes in biomaterials was rather seen in the production of porous scaffolds of polymeric origin, such as polycaprolactone [40], gelatin [41], polyurethane [42, 43], silk fibroin [44], polylactic-co-glycolic acid (PLGA) [45, 46], poly-L-lactic acid (PLLA) [47, 48], polypropylene fumarate [49], copoly-L-lactide-epsilon-caprolactone [50], and polymethylmetacrylate [51].

Granulation, as it is understood and commonly used in the pharmaceutical industry, is the process in which powder particles are made to adhere (with the help of a binder that locks the powders together as granules and prevents disintegration) to form larger entities called granules. Pharmaceutical granules [52-55] typically assume sizes between 0.2 and $4.0 \mathrm{~mm}$, and in orthopedic surgery granules between 1 and $2 \mathrm{~mm}[36,38]$, whereas in periodontal surgery granule sizes of $0.25-1 \mathrm{~mm}$ are preferred [56]. Therefore, it would not have been unusual to inspire from the granulation processes and procedures of pharmaceutical industry to produce $\mathrm{CaP}$ granules for skeletal repair and biomedical applications.

Pharmaceutical industry typically uses planetary mixers, fluidized-bed granulators, spheronizers, rotors, extruders and pelletizers in forming granules from wet masses containing the desired ingredients [57]. However, sieving (or screening), in pharmaceutical granulation technology, is only regarded as a secondary tool of transforming the as-formed granules into monosized granules.

The spherical granules of the current study, which used a well-tested and documented $\mathrm{CaP}$ cement powder as the starting material [58-61], did not need any sintering or high-temperature calcination to develop their handling strength. The granules of carbonated and Ca-deficient Ap-CaP stoichiometry were formed and in situ hardened at the ambient temperature by the cement setting reaction. Cement reaction directly took place on an automatic sieve shaker and this sieve shaker was the sole granulation device.

The porous granules reported in this study are believed to be the first spherical granules produced at the ambient temperature from a self-setting $\mathrm{CaP}$ cement dough by simple sieving.

\section{Materials and methods}

Powders of self-setting cement Calcibon ${ }^{\circledR}$ (Biomet-Merck Biomaterials GmbH, Darmstadt, Germany) were used to 
form the porous granules. The cement powder [57-60] consisted of a mixture of $61 \% \alpha$-TCP, $26 \% \mathrm{CaHPO}_{4}, 10 \%$ $\mathrm{CaCO}_{3}$ and $3 \% \mathrm{HA}$, by weight. A 3.5 wt.\% solution of $\mathrm{Na}_{2} \mathrm{HPO}_{4}$ powder $(99.9 \%$ pure, Merck KGaA, Darmstadt) in deionized water was its initiator liquid. $\mathrm{NaCl}(99.9 \%$, Merck KGaA, Darmstadt) was used as the porogen. The as-received $\mathrm{NaCl}$ powder was first screened by using two sieves, mesh no. 18 (1.0 mm sieve opening) and no. 40 (420 $\mu \mathrm{m}$ sieve opening). Therefore, the $\mathrm{NaCl}$ porogen crystals used in granule synthesis were varying in size between $420 \mu \mathrm{m}$ and $1 \mathrm{~mm}$, and about $85 \%$ by weight of the $\mathrm{NaCl}$ crystals were smaller than $500 \mu \mathrm{m}$. The particle size distribution of the $\mathrm{NaCl}$ porogen powders was determined by sieve analysis.

Granule preparation method comprised the successive steps of

(1) dry mixing $40.0 \mathrm{~g}$ of the cement powder with $70.0 \mathrm{~g}$ of $\mathrm{NaCl}$ in a Turbula ${ }^{\circledR} \mathrm{T} 2 \mathrm{~F}$ mixer for $90 \mathrm{~min}$ in a polyethylene bottle,

(2) wetting the powder with an appropriate volume of a mixture of high-purity ethanol $(99.9 \%$, Merck KGaA, Darmstadt) and 3.5 wt. $\% \mathrm{Na}_{2} \mathrm{HPO}_{4}$ aqueous solution (i.e., $6.7 \mathrm{~mL}$ ethanol mixed with a $12 \mathrm{~mL}$ aliquot of 3.5 wt. $\% \mathrm{Na}_{2} \mathrm{HPO}_{4}$ solution),

(3) kneading the wet powder body for 4 min to form a dough with a special mixer in a glass container,

(4) immediately sieving that wet dough within the following $2 \mathrm{~min}$ in an automatic sieve shaker, with multiple plastic sieves, to in situ form granules of desired sizes,

(5) drying the as-formed granules in static air for $1 \mathrm{~h}$,

(6) leaching out the $\mathrm{NaCl}$ porogen by soaking the granules in a sterile glass container with circulating distilled water at room temperature for $48 \mathrm{~h}$,

(7) checking the efficiency of leaching (of $\mathrm{NaCl}$ ) by measuring the conductivity of the washing water at regular intervals, and

(8) drying the washed granules at $37{ }^{\circ} \mathrm{C}$ in an aircirculated oven for $24 \mathrm{~h}$ in glass trays.

In a typical sieving/granulation run, the following stack of sieves was used: mesh no. $18(1.0 \mathrm{~mm})$, mesh no. 16 $(1.19 \mathrm{~mm})$, mesh no. $10(2.0 \mathrm{~mm})$, mesh no. $7(2.83 \mathrm{~mm})$ and mesh no. $5(4.00 \mathrm{~mm})$. The nominal sieve openings were given above in parenthesis next to the mesh numbers.

Conductivities of the $\mathrm{NaCl}$ leach-out solutions were measured by using a commercial electrolytic conductivity meter (Hanna Instruments, Model 98311, Kehl am Rhein, Germany). 1,000 ppm NaCl-containing solutions had a conductivity of around $2,000 \mu \mathrm{S} / \mathrm{cm}$ at $21{ }^{\circ} \mathrm{C}$. Washing of the granules was continued until a conductivity reading of $1 \mu \mathrm{S} / \mathrm{cm}$ reached, which was a value close to that of distilled water. Granule washing baths reached that level of low conductivity after $24-32 \mathrm{~h}$ of soaking.

Granules were characterized by scanning electron microscopy (SEM, Model JEOL630, Jeol Corp., Tokyo, Japan), energy-dispersive X-ray spectroscopy (EDXS, Thermo-Kevex, San Jose, CA), powder X-ray diffraction (XRD, $\mathrm{Cu} \mathrm{K} \alpha$ radiation, Model D5000, Siemens GmbH, Karlsruhe, Germany), Fourier-transformed infrared spectroscopy (FTIR, Model Nicolet 550, Thermo-Nicolet, Woburn, MA), ICP-AES analyses (Model 61E, Thermo Electron, Madison, WI), density (Pycnometer, Model AccuPyc 1330, Micromeritics, Norcross, GA), compressive strength measurements (Model 4500, Instron Deutschland GmbH, Germany), and BET surface area measurements (Model ASAP 2020, Micromeritics Corp., Norcross, GA). The water absorption percentage determination required the granule samples to be first boiled in water and then remain submerged while the water was naturally cooling and filling the pores. The samples were first weighed dry, then weighed while suspended in water, and weighed after superficial drying to obtain the desired information. This testing method was described in ASTM Standard Test Method C20-92 [62].

Samples were coated with a 50-70 nm-thick layer of carbon prior to SEM imaging. EDXS analyses were performed on the carbon-coated granule samples to detect any residual chlorine, after the washing step. XRD data were gathered over the $2 \theta$ range of $10-60^{\circ}$, by using a step size of 0.02 and a preset time of $1 \mathrm{s.} 35 \mathrm{~mA}$ and $40 \mathrm{kV}$ were the respective power and voltage settings of the $\mathrm{X}$-ray diffractometer. FTIR analyses, on the other hand, were performed after diluting the pulverized (into a fine powder) granule samples in IR-grade $\mathrm{KBr}$ at the sample-to- $\mathrm{KBr}$ weight ratio of $1: 100$, followed by pelletizing in a $1 \mathrm{~cm}$ steel die at $25 \mathrm{MPa}$. Granule densities were measured by using a standard gas pycnometer. During the ICP-AES analyses of dried granules, $50 \mathrm{mg}$ portions of samples were dissolved in $5 \mathrm{~mL}$ of concentrated $\mathrm{HNO}_{3}$ solution. Compressive strength measurements were performed after filling a $2.5 \mathrm{~cm}$-diameter stainless steel die with granules (just enough to form a monolayer of granules), followed by gentle tapping of the die to facilitate the even packing of granules. An automated Instron universal testing machine was used to push the upper punch into the die cavity at the crosshead speed of $1 \mathrm{~mm} / \mathrm{min}$. The BET surface area of the 2-2.8 mm granules was determined by applying the standard Brunnauer-Emmet-Teller method to the nitrogen adsorption isotherms obtained at $-196{ }^{\circ} \mathrm{C}$ using the Micromeritics ASAP 2020 instrument.

To test the compressive strength of the as-synthesized granules, about 20 granules $(2-2.8 \mathrm{~mm}$ in diameter) were evenly placed, in the form of a monolayer as much as possible, onto the surface of the lower punch inserted from 
bottom into the circular cavity of a stainless steel die ( $2.5 \mathrm{~cm}$ in diameter), followed by gently placing the upper punch directly onto the granules. For measuring the compressive load-bearing capacities of granules, the abovementioned die assembly was placed between the load plates of the Instron machine. The applied force versus displacement curves of granules originated from seven different production batches were recorded at $20 \pm 1{ }^{\circ} \mathrm{C}$, $50 \%$ relative humidity and a crosshead speed of $1 \mathrm{~mm} / \mathrm{min}$ under compression.

Additionally, granules pre-packed in the bone grafting system $\mathrm{VacPac}^{\mathrm{TM}}$ (Biomet, Inc., Warsaw, IN) were soaked with citrated blood. In brief, six times $9 \mathrm{~mL}$ of whole blood of healthy donors of either gender was drawn into $10 \mathrm{~mL}$ Monovettes $^{\mathrm{TM}}$ (Sarstedt, Germany) containing $1 \mathrm{~mL}$ of $0.106 \mathrm{M}$ sodium citrate solution commercially available $\mathrm{VacPac}^{\mathrm{TM}}$ provided $10 \mathrm{~cm}^{3}$ of dry cancellous allograft prepacked under vacuum suction that could easily be hydrated completely with, for instance, PRP (platelet-rich plasma). For the experiments each $5 \mathrm{~cm}^{3}$ of granules were prepacked in a $\mathrm{VacPac}^{\mathrm{TM}}$ pouch and sterilized by gamma irradiation. Citrated blood was activated by adding the donor's autologous thrombin to a ratio of 1:10 and quickly each $6 \mathrm{~mL}$ of the activated blood product were used to soak the granules. Autologous thrombin was produced by collecting $9 \mathrm{~mL}$ of whole blood into a Serum Gel Monovette $^{\mathrm{TM}}$ (Sarstedt, Germany) and centrifugation of the clot for $5 \mathrm{~min}$ at $1,800 \mathrm{rcf}$. The serum supernatant containing the autologous thrombin stabilized by the fibrin clot [63] was carefully recovered and calcified with a $10 \%$ (w/w) $\mathrm{CaCl}_{2}$ solution (1:4) prior to use. For clot formation and retraction the VacPacs ${ }^{\mathrm{TM}}$ were incubated at $37^{\circ} \mathrm{C}$ for $1 \mathrm{~h}$ and overnight at $4{ }^{\circ} \mathrm{C}$.

\section{Results and discussion}

The photograph of Fig. 1a showed the as-formed granules in two different sizes $(2.8-4 \mathrm{~mm}$ and $2-2.8 \mathrm{~mm}$, respectively). The size distribution of $\mathrm{NaCl}$-containing granules obtained in one typical setting-sieving batch (i.e., wet cement dough was set in situ during sieving) was given in Table 1. The weight percentages given in Table 1 were the average values obtained from ten separate runs. Size distribution could be slightly altered by varying the L/P (liquid-to-powder) ratio of the $\mathrm{NaCl}$-containing cement dough placed onto the sieve shaker (data not shown). The discussion of the effect of $\mathrm{L} / \mathrm{P}$ ratio was left outside the scope of this manuscript. $\mathrm{NaCl}$ leachout did not change the granule size distributions.

Figure $1 \mathrm{~b}$ exhibited the low-magnification SEM photomicrograph of the obtained spherical granules, and the cubic imprints of the embedded $\mathrm{NaCl}$ porogen crystals were visible. $\mathrm{NaCl}$ porogen crystals were totally leached out upon washing. In other words, $\mathrm{NaCl}$ crystals left behind their footprints. Those square nests formed (after dissolution of these $\mathrm{NaCl}$ crystals) in the calcium phosphate cement matrix were like the "replicas" of those crystals,
Fig. 1 (a) Photograph of porous granules shown at two different sizes, (b) low magnification SEM image showing the nests of $\mathrm{NaCl}$ porogen crystals, (c) and (d) high magnification images detailing the microstructure of carbonated, apatitic $\mathrm{CaP}$ microporous cement matrix
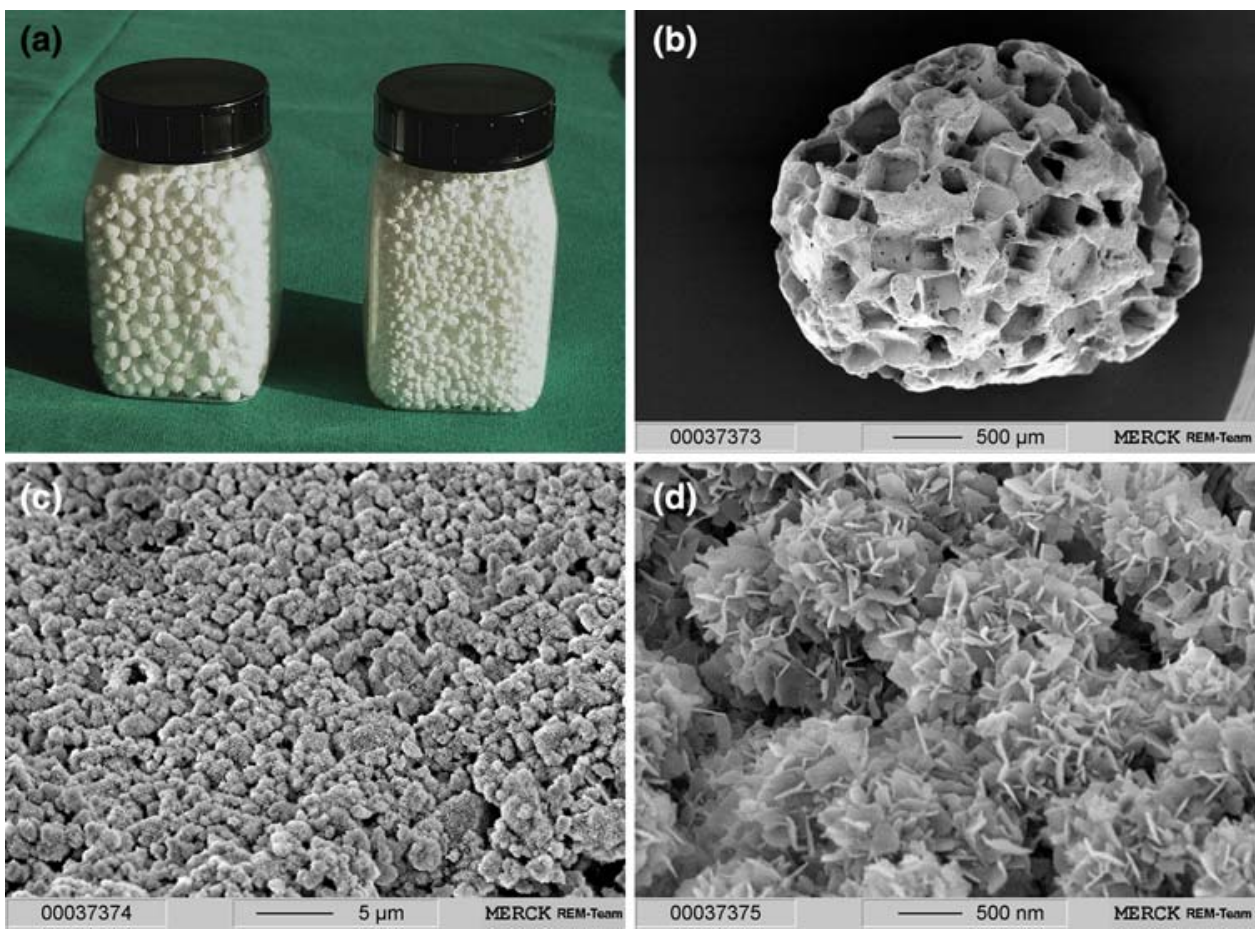
Table 1 Granule size distribution $^{\mathrm{a}}$

${ }^{a}$ Sizes were given in accord with the mesh numbers of sieves used

and thus the product could be identified according to its manufacturing process. Macropores, being simply dependent on the crystal size of $\mathrm{NaCl}$ used in processing, could be readily varied over the range of $50-800 \mu \mathrm{m}$. However, for the sample shown in Fig. 1b, pore sizes were from 50 to $400 \mu \mathrm{m}$.

High-magnification SEM photomicrographs of the granules given in Fig. 1c, d consecutively zoomed into the microporous matrices (i.e., the dense looking areas of Fig. 1b) of the granules. The three-dimensional microporosity ranged in size from 1 to $4 \mu \mathrm{m}$, as seen in Fig. 1c. Since the cement of this study, i.e., Calcibon ${ }^{\circledR}$, was an $\alpha$-TCP-based cement [64-66], with the major additives of $\mathrm{CaHPO}_{4}$ and $\mathrm{CaCO}_{3}$, upon setting within 7-8 min, it formed a web of interlocking and intermingling nanosize platelets (as shown in Fig. 1d) of Ca-deficient apatitic CaP with a $\mathrm{Ca} / \mathrm{P}$ molar ratio of $1.52 \pm 0.1$. This $\mathrm{Ca} / \mathrm{P}$ molar ratio was determined by ICP-AES analyses and reported as the average of seven different samples. Granulation process used in this study did not alter or destroy the cement stoichiometry (by ICP-AES and XRD data not shown) either prior to or after granulation.

"Biological" or "bone-like" apatite, which constitutes the bone mineral, is known to be a carbonated (410 wt.\%), poorly crystallized, alkali (i.e., $\mathrm{Na}$ and $\mathrm{K}$ ) and alkaline earth $(\mathrm{Mg})$ element-doped, non-stoichiometric, calcium-deficient apatitic phosphate with a $\mathrm{Ca} / \mathrm{P}$ molar ratio variable over the range of 1.50-1.70 [67-69]. The $\mathrm{CaP}$ cement used in the production of the porous granules of this study was previously shown to yield a fast deposition of new bone at the cement surface in its paste form [70].

XRD analysis of these granules yielded the characteristic poorly crystallized apatitic $\mathrm{CaP}$ spectra, as shown in Fig. 2a. The complete setting reaction for this high strength (>55 MPa under compression) cement has been described elsewhere in detail [64-66]. However, to mention briefly, the major component of this cement, i.e., $\alpha-\mathrm{Ca}_{3}\left(\mathrm{PO}_{4}\right)_{2}$, went through a hydrolysis reaction upon its contact with the setting solution of $\mathrm{pH}$ 9. The major end-product of the hydrolysis reaction was $\mathrm{Ca}$-deficient apatitic $\mathrm{CaP} . \mathrm{CaCO}_{3}$

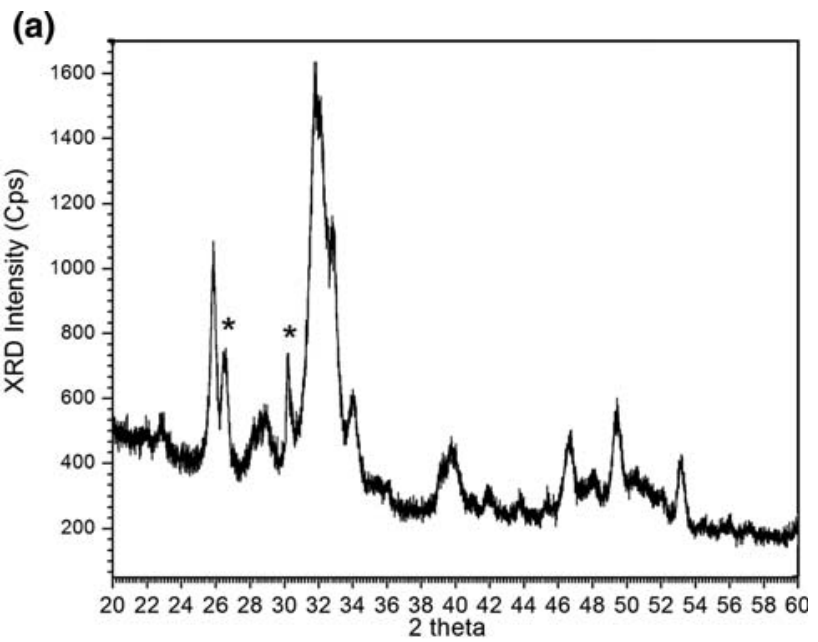

(b)

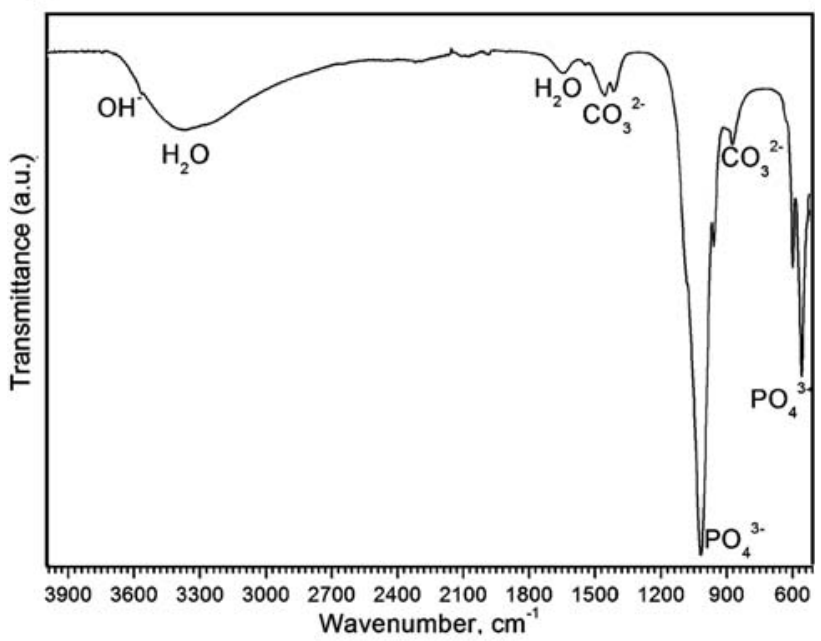

(c)

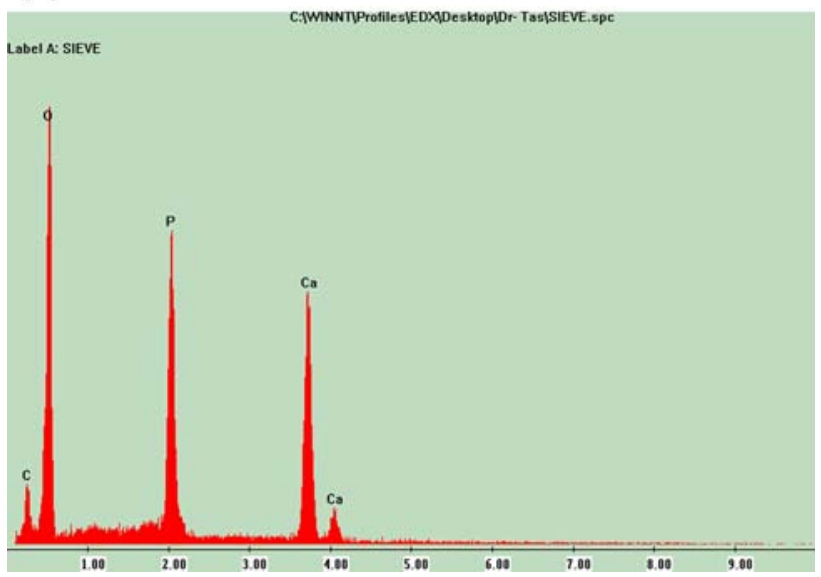

Fig. 2 (a) characteristic XRD trace of granules immediately after production ( ${ }^{*} \mathrm{CaHPO}_{4}$ peaks, rest: apatitic $\mathrm{CaP}$ peaks), (b) FTIR spectrum of granules and (c) EXDS spectrum of granules 
present in the cement powder rapidly participated in this hydrolysis process facilitating the formation of carbonated, apatitic $\mathrm{CaP}$ [71]. Although a slow process, $\mathrm{CaHPO}_{4}$ itself also underwent a similar hydrolysis procedure to the apatitic $\mathrm{CaP}$, and the small amount of precipitated HA present in the cement formulation acted as an accelerator for those hydrolysis processes, which continued at the body temperature till the completion of the cement setting. The XRD data given in Fig. 2a belonged to the freshly produced porous granules after washing off of the $\mathrm{NaCl}$ porogen crystals in deionized water at $37{ }^{\circ} \mathrm{C}$ for $48 \mathrm{~h}$, i.e., after step 7, but prior to step $8 . \mathrm{CaHPO}_{4}$ was present as a secondary phase in the as-formed granules, which was also the case for the setting of $\mathrm{NaCl}$-free cement samples [61]. Presence of $\mathrm{NaCl}$ crystals in granule production by using this cement did not affect the cement setting process. The absence of $\mathrm{NaCl}$ peaks in the XRD traces proved the efficiency of the washing process.

The carbonated and bone-like nature of the porous granules was strongly indicated by the characteristic $\mathrm{CO}_{3}^{2-}$ bands seen at 873 and $1,450 \mathrm{~cm}^{-1}$ in the FTIR data of Fig. $2 \mathrm{~b}$. The weak band seen at $3,571 \mathrm{~cm}^{-1}$ belonged to the $\mathrm{OH}$ stretching. Orthophosphate bands were also observed at their characteristic positions [72].

EDXS analyses performed on the washed granules showed that they did not contain any $\mathrm{Na}^{+}$or $\mathrm{Cl}^{-}$ions originating from the use of $\mathrm{NaCl}$ as the porogen. EDXS results (accurate to \pm 0.5 wt.\%), shown in Fig. 2c, only exhibited the extraneous $\mathrm{C}$ peaks due to the carbon coating of granules prior to the analysis.

The formed granules (between 2 and $4 \mathrm{~mm}$ sizes) had a pycnometrically determined density of $1.60 \pm 0.15 \mathrm{~g} / \mathrm{cm}^{3}$, which corresponded to about $50 \%$ total porosity, considering the fact that the density of the fully set, fully dense Calcibon ${ }^{\circledR}$ cement was around $3.2 \mathrm{~g} / \mathrm{cm}^{3}$ [64-66]. Porous granules also possessed a water absorption percentage of 150 , measured according to the aforementioned ASTM standard [62]. This property itself imparted the granules a significant wicking ability [73]. Percentage macro- and microporosity values would have best been determined by using, for instance, computerized tomography techniques; however, based on our available density and water absorption percentage data the total porosity in all the granule synthesis batches (either at the laboratory-scale or in the up-scaling batches) was never recorded to be less than $50 \%$.

Compressive strength measurements performed on monolayers of around 20 granules $(2<\mathrm{x}<2.8 \mathrm{~mm}$ in diameter) are presented in Fig. 3. For each test a more or less jagged (zigzag) graph was initially recorded. Due to differences in sizes between the assembled granules, the method used to measure the compressive strength of granules would inevitably result in not all of the granules

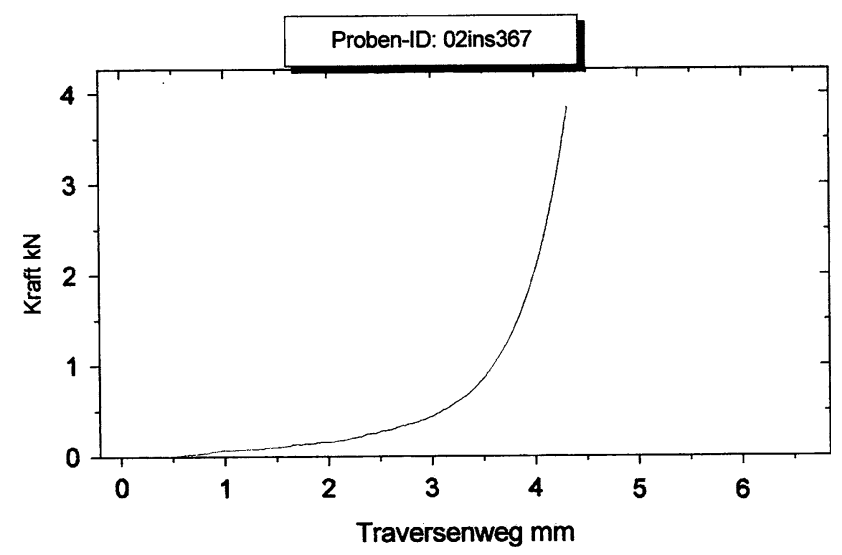

Fig. 3 Applied load (Kraft) versus displacement (Traversenweg) curve of as-synthesized granules

being compressed at the exact same time. In other words, the smaller granules would not be compressed until the larger granules have been slightly compressed. The characteristic data presented in Fig. 3 corresponded to a maximum failure load of $3.87 \pm 0.11 \mathrm{kN}$ and to $3.83 \pm 0.09 \mathrm{~mm}$ displacement at the maximum load. These values translated to a compressive strength of $10.19 \pm 0.16 \mathrm{MPa}$. The traces obtained from seven different batches of granules were almost perfectly reproducing one another; in other words, compressive strength tests were not alone able to tell the differences between production batches, if there were any.

As presented in Fig. 4, the granules were tightly fixed within a clotted citrated blood, and the visible macropores were readily filled with blood. Nevertheless, the granules were not completely soaked with citrated blood as the white color of the calcium phosphate could still be seen clearly. To test whether the granules were completely soaked with blood, the granules were recovered after maximal clot retraction, embedded in a resin and a polished

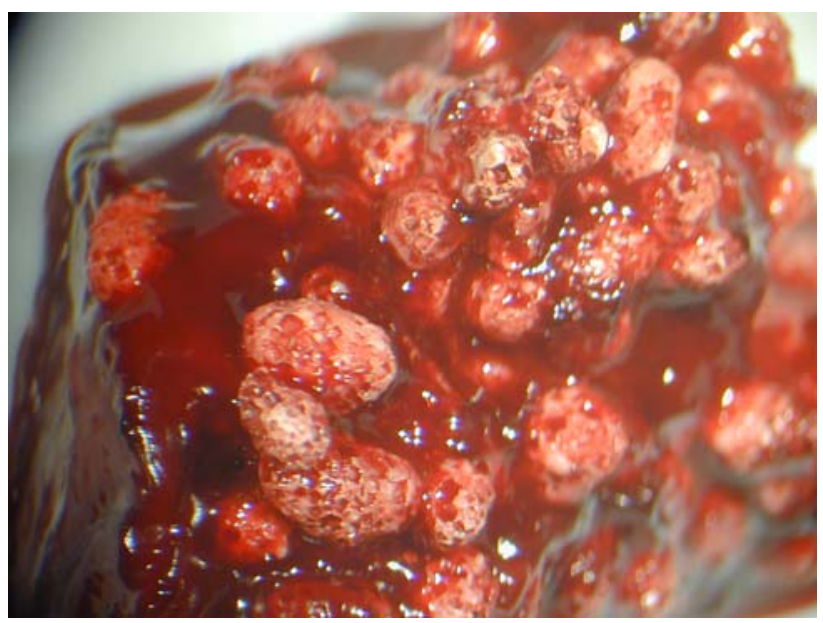

Fig. 4 Photograph of tightly fixed granules within clotted citrated blood 
section was obtained by grinding (Fig. 5). As can be seen, the granules manually mixed (Fig. 5a) with citrated blood were soaked with less blood than the granules that had been pre-packed in the $\mathrm{VacPac}^{\mathrm{TM}}$ system (Fig. 5b).

The cement liquid (3.5 wt.\% $\mathrm{Na}_{2} \mathrm{HPO}_{4}$ solution), when mixed with the cement powder of this study, resulted in a smooth and malleable calcium phosphate paste. This paste showed the ability of seamlessly embracing and surrounding the cubic $\mathrm{NaCl}$ crystals. The use of ethanol in the granule manufacturing was only for the purpose of retarding the setting reaction for a few more minutes to allow successful sieving. Ethanol used was either evaporated or washed away with water during the later, washing-drying stages of the granule manufacturing process. During leaching out of the embedded $\mathrm{NaCl}$ crystals, the effluent solutions were monitored with respect to their electrolytic conductivity on a real time basis. It is known that even ppm levels of dissolved $\mathrm{NaCl}$ in water would cause an increase in the conductivity values of such solutions. Washing operation was terminated when the conductivity of the effluent solutions reached the level of almost that of distilled water (i.e., $1 \mu \mathrm{S} / \mathrm{cm}$ ).
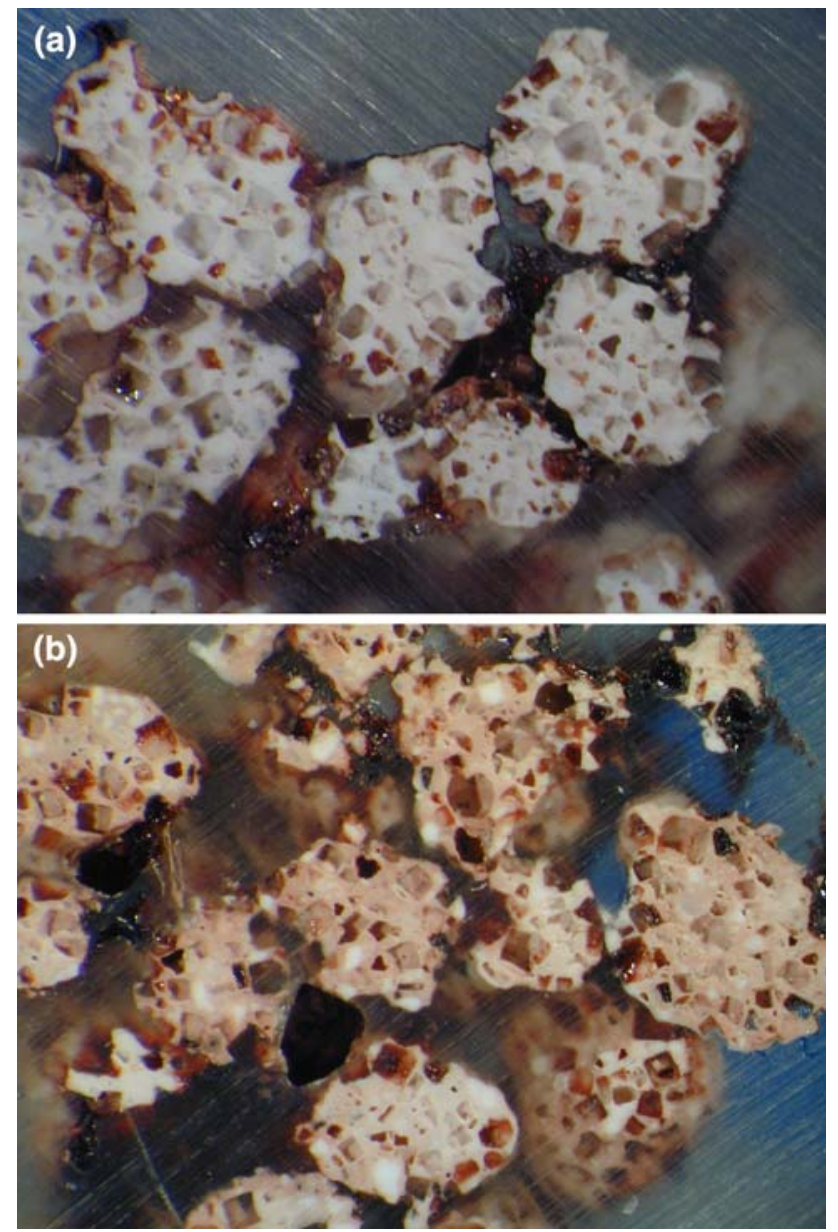

Fig. 5 Polished sections of granules (a) manually mixed with citrated blood and (b) pre-packed in the $\mathrm{VacPac}^{\mathrm{TM}}$ system
The wet, freshly formed granules hardened at the ambient temperature by an endothermic reaction. The chemical composition and crystalline structure of the cured material did mimic the mineral part of natural bone, as depicted especially in the IR spectrum of Fig. $2 b$.

Tadic et al. [74] used a $\mathrm{NaCl}$ porogen technique similar to ours to produce macropores with pore diameters in the range of $250-400 \mu \mathrm{m}$ in CaP scaffolds. Nevertheless, their starting material was just a precipitated hydroxyapatite in powder form, which was far from being a self-setting cement. In order not to cause any undesired grain growth and a decrease in the surface reactivity of their powders, they apparently did not calcine their precipitated powders, and used such powders as received. Tadic et al. [74] unfortunately needed to compact their $\mathrm{NaCl}$-embedded hydroxyapatite powder blocks by using cold isostatic pressing. Since they did not sinter their 3D objects, after porogen removal and consequent pore formation, it was not possible to mention any handling strength to be present in such devices for the orthopedic surgeon. The abovementioned report [74] constituted a vivid example on the significance of using strong self-setting cements in forming porous CaP-based medical devices by the porogen technique. Formation of macropores in a TTCP $\left(\mathrm{Ca}_{4}\left(\mathrm{PO}_{4}\right)_{2} \mathrm{O}\right)$-based cement paste was previously shown by Takagi and Chow [75] and they used either sucrose, $\mathrm{NaHCO}_{3}$ or $\mathrm{Na}_{2} \mathrm{HPO}_{4}$ crystals $(125-250 \mu$ m particles) as the porogen. The loading of the porogen crystals was much lower $(33 \%)$ than that employed in the current study (65\%). Moreover, Takagi and Chow [75] pressed (at $2 \mathrm{MPa}$ ) their porogen + cement pastes into well-defined cylindrical shapes by using a steel die. Xu et al. [76] used mannitol as the porogen to produce macropores in a TTCP $\left(\mathrm{Ca}_{4}\left(\mathrm{PO}_{4}\right)_{2} \mathrm{O}\right)$-based cement. Lee et al. [77], on the other hand, used carbonated mixtures of $\mathrm{Ca}(\mathrm{OH})_{2}$ and $\mathrm{NaCl}$ to form macroporous $\mathrm{CaCO}_{3}$ scaffolds. Guan and Davies [78] had tried PLGA as the porogen in a TTCP-monetite cement.

The granules of the present study regarded to be onetime skeletal repair implants which shall stay in place until their potential complete biodegradation (by the osteoclastic resorption) by the body. According to Bohner and Baumgart [79], the in vivo resorption rate of porous granules can be theoretically predicted to be much faster than the dense blocks or prismatic objects made out of the same material. Depending on the indication, accurate repositioning, as well as fixation or stabilization, of the granules should be performed as if using an autologous bone graft [80]. Such granules should be intended for filling and reconstruction of large, aseptic, metaphyseal, cancellous bone defects. These bone defects might be caused by trauma or other genesis, e.g., a benign tumor, from surgery or congenital. 
Calcium phosphate bone substitutes impregnated with, for instance, bone marrow aspirate (BMA) [81], autologous platelet-rich plasma (PRP) [82], osteocalcin [83] or mesenchymal stem cells [84] were already shown to significantly improve the skeletal repair abilities of the otherwise pristine materials. Therefore, these granules are expected to perform better in vivo when they are first impregnated with PRP or BMA and then used.

\section{Conclusions}

Micro- and macroporous carbonated, apatitic calcium phosphate granules for skeletal repair were produced by the $\mathrm{NaCl}$ porogen technique by using a self-setting $\mathrm{CaP}$ cement powder as the starting material. The high strength $\mathrm{CaP}$ cement used here facilitated the economical production of porous granules.

(1) The simple process used in granule manufacturing allowed the precise selection and specification of the final granule sizes over the range of $2-4 \mathrm{~mm}$,

(2) Pore sizes over the range of 50-550 $\mu \mathrm{m}$ were readily achieved,

(3) Granules had about 50\% porosity,

(4) Granules were produced from totally synthetic materials, such as $\alpha-\mathrm{Ca}_{3}\left(\mathrm{PO}_{4}\right)_{2}, \mathrm{CaHPO}_{4}, \mathrm{CaCO}_{3}$ and $\mathrm{Ca}_{10}\left(\mathrm{PO}_{4}\right)_{6}(\mathrm{OH})_{2}$,

(5) Granules comprised of carbonated, calcium-deficient, poorly crystallized apatitic $\mathrm{CaP}$ phase with a $\mathrm{Ca} / \mathrm{P}$ molar ratio of $1.52 \pm 0.1$,

(6) Granules had a high water absorption percentage (ca. $150 \%$ ),

(7) Granules were produced at the ambient temperature.

Acknowledgements This study was performed in "Merck Biomaterials GmbH" and "Biomet-Merck Biomaterials GmbH" of Darmstadt, Germany, between September 2001 and March 2003, when the author was previously working there as a staff research scientist. The author is cordially grateful to Dr. Daniel L. Zukowski for performing the clotted blood experiments on the granules.

\section{References}

1. H. OONISHI, L. L. HENCH, J. WILSON, F. SUGIHARA, E. TSUJI, S. KUSHITANI and H. IWAKI, J. Biomed. Mater. Res. 44 (1999) 31

2. R. Z. LEGEROS, Clin. Orthop. Rel. Res. 395 (2002) 81

3. I. R. GIBSON, S. KE, S. M. BEST and W. BONFIELD, J. Mater. Sci. Mater. M. 12 (2001) 163

4. H. S. CHEUNG, In Vitro Cell. Dev. B 21 (1985) 353

5. K. ONO, T. YAMAMURO, T. NAKAMURA and T. KOKUBO, Biomaterials 11 (1990) 265

6. A. M. GATTI, D. ZAFFE and G. P. POLI, Biomaterials 11 (1990) 513
7. J. M. SAUTIER, J. R. NEFUSSI, H. BOULEKBACHE and N. FOREST, In Vitro Cell. Dev. B 26 (1990) 1079

8. K. YAMAMURA, H. IWATA and T. YOTSUYANAGI, J. Biomed. Mater. Res. 26 (1992) 1053

9. H. YAMASAKI and H. SAKAI, Biomaterials 13 (1992) 308

10. H. S. BYRD, P. C. HOBAR and K. SHEWMAKE, Plast. Reconstr. Surg. 91 (1993) 15

11. K. G. WIESE and H. A. MERTEN, Int. J. Oral Maxillofac. Surg. 22 (1993) 306

12. T. C. LINDHOLM, T. J. GAO and T. S. LINDHOLM, Int. J. Oral Maxillofac. Surg. 23 (1994) 306

13. M. FABBRI, G. C. CELOTTI and A. RAVAGLIOLI, Biomaterials 15 (1994) 474

14. E. A. HOLTGRAVE and K. DONATH, Biomaterials 16 (1995) 155

15. E. T. BARAN, K. TUZLAKOGLU, A. J. SALGADO and R. L. REIS, J. Mater. Sci. Mater. M. 15 (2004) 161

16. P. LUO and T. G. NIEH, Biomaterials 17 (1996) 1959

17. N. KAWAI, S. NIWA, M. SATO, Y. SATO, Y. SUWA and I. ICHIHARA, J. Biomed. Mater. Res. 37 (1997) 1

18. D. M. LIU, Biomaterials 17 (1996) 1955

19. Z. ZYMAN, V. GLUSHKO, V. FILIPPENKO, V. RADCHENKO and V. MEZENTSEV, J. Mater. Sci. Mater. M. 15 (2004) 551

20. M. MARUYAMA and M. ITO, J. Biomed. Mater. Res. 32 (1996) 527

21. H. GAUTHIER, J. GUICHEUX, G. GRIMANDI, A. FAIVRECHAUVET, G. DACULSI and C. MERLE, J. Biomed. Mater. Res. 40 (1998) 606

22. H. OONISHI, Y. KADOYA, H. IWAKI and N. KIN, J. Biomed. Mater. Res. 53 (2000) 174

23. M. A. W. MERKX, J. C. MALTHA, H. P. M. FREIHOFER and A. M. KUIJPERS-JAGTMAN, Biomaterials 20 (1999) 2029

24. W. PAUL and C. P. SHARMA, J. Mater. Sci. Mater. M. 10 (1999) 383

25. N. PATEL, S. M. BEST, W. BONFIELD, I. R. GIBSON, K. A. HING, E. DAMIEN and P. A. REVELL, J. Mater. Sci. Mater. M. 13 (2002) 1199

26. C. SCHWARTZ, P. LISS, B. JACQUEMAIRE, P. LECESTRE and P. FRAYSSINET, J. Mater. Sci. Mater. M. 10 (1999) 821

27. C. TANAKA, J. SHIKATA, M. IKENAGA and M. TAKAHASHI, J. Arthroplasty 18 (2003) 719

28. V. S. KOMLEV, S. M. BARINOV and E. V. KOPLIK, Biomaterials 23 (2002) 3449

29. V. S. KOMLEV and S. M. BARINOV, J. Mater. Sci. Mater. M. 13 (2002) 295

30. L. M. RODRIGUEZ-LORENZO, M. VALLET-REGI and J. M. F. FERREIRA, J. Biomed. Mater. Res. 60 (2002) 232

31. L. L. GUEHENNEC, E. GOYENVALLE, E. AGUADO, P. PILET, R. SPAETHE and G. DACULSI, J. Mater. Sci. Mater. M. 18 (2007) 1489

32. M. P. FERRAZ, A. Y. MATEUS, J. C. SOUSA and F. J. MONTEIRO, J. Biomed. Mater. Res. 81A (2007) 994

33. P. WEISS, P. LAYROLlE, L. P. CLERGEAU, B. ENCKEL, P. PILET, Y. AMOURIQ, G. DACULSI and B. GIUMELLI, Biomaterials 28 (2007) 3295

34. J. J. C. ARTS, L. H. B. WALSCHOT, N. VERDONSCHOT, B. W. SCHREURS and P. BUMA, J. Biomed. Mater. Res. 81B (2007) 476

35. O. L. KUBAREV, V. S. KOMLEV, S. M. BARINOV, N. S. SERGEEVA, I. K. SVIRIDOVA, V. A. KIRSANOVA and S. A. AKHMEDOVA, Doklady Chem. 409 (2006) 124

36. H. H. HORCH, R. SADER, C. PAUTKE, A. NEFF, H. DEPPE and A. KOLK, Int. J. Oral Maxillofac. Surg. 35 (2006) 708

37. C. C. RIBEIRO, C. C. BARRIAS and M. A. BARBOSA, J. Mater. Sci. Mater. M. 17 (2006) 455 
38. D. ZAFFE, Micron 36 (2005) 583

39. D. L. NIHOUANNEN, G. DACULSI, A. SAFFARZADEH, O. GAUTHIER, S. DELPLACE, P. PILET and P. LAYROLLE, Bone 36 (2005) 1086

40. L. OLAH, K. FILIPCZAK, Z. JAEGERMANN, T. CZIGANY, L. BORBAS, S. SOSNOWSKI, P. ULANSKI and J. M. ROSIAK, Polym. Adv. Technol. 17 (2006) 889

41. H. G. KANG, S. Y. KIM and Y. M. LEE, J. Biomed. Mater. Res. 79B (2006) 388

42. H. HAUGEN, J. WILL, W. FUCHS and W. WINTERMANTEL, J. Biomed. Mater. Res. 77B (2006) 65

43. S. IANNACE, E. DI MAIO and L. NICOLAIS, Cell. Polym. 20 (2001) 321

44. H. J. KIM, H. S. KIM, A. MATSUMOTO, I. J. CHIN, H. J. JIN and D. L. KAPLAN, Aust. J. Chem. 58 (2005) 716

45. H. R. LIN, C. J. KUO, C. Y. YANG, S. Y. SHAW and Y. J. WU, J. Biomed. Mater. Res. 63 (2002) 271

46. J. C. ZHANG, L. B. WU, D. Y. JING and J. D. DING, Polymer 46 (2005) 4979

47. S. H. LEE, B. S. KIM, S. H. KIM, S. W. KANG and Y. H. KIM, Macromol. Biosci. 4 (2004) 802

48. J. B. MCGLOHORN, W. D. HOLDER, L. W. GRIMES, C. B. THOMAS and K. J. L. BURG, Tissue Eng. 10 (2004) 505

49. J. P. FISHER, T. A. HOLLAND, D. DEAN, P. S. ENGEL and A. G. MIKOS, J. Biomater. Sci. -Polym. Ed. 12 (2001) 673

50. J. H. DEGROOT, H. W. KUIJPER and A. J. PENNINGS, J. Mater. Sci. Mater. M. 8 (1997) 707

51. K. FILIPCZAK, I. JANIK, M. KOZICKI, P. ULANSKI, J. M. ROSIAK, L. A. PAJEWSKI, R. OLKOWSKI, P. WOZNIAK, A. CHROSCICKA and M. LEWANDOWSKA-SZUMIEL, E-Polymers Art. No. 011 (2005)

52. A. FAURE, P. YORK and R. C. ROWE, Eur. J. Pharm. Biopharm. 52 (2001) 269

53. K. TAKANO, K. NISHII, A. MUKOYAMA, Y. IWADATE, H. KAMIYA and M. HORIO, Powder Technol. 122 (2002) 212

54. J. WERANI, M. GRUNBERG, C. OBER and H. LEUENBERGER, Powder Technol. 140 (2004) 163

55. C. VERVAET and J. P. REMON, Chem. Eng. Sci. 60 (2005) 3949

56. R. E. JUNG, C. H. F. HAEMMERLE, V. KOKOVIC and F. E. WEBER, Int. J. Oral Maxillofac. Implants. 22 (2007) 258

57. D. M. PARIKH, "Handbook of Pharmaceutical Granulation Technology", 2nd edn (CRC Press, New York, 2005)

58. I. KHAIROUN, M. G. BOLTONG, F. C. M. DRIESSENS and J. A. PLANELL, Biomaterials 18 (1997) 1535

59. E. M. OOMS, J. G. C. WOLKE, J. P. C. M. VAN DER WAERDEN and J. A. JANSEN, J. Biomed. Mater. Res. 66B (2003) 447

60. E. M. OOMS, J. G. C. WOLKE, J. P. VAN DER WAERDEN and J. A. JANSEN, J. Biomed. Mater. Res. 61 (2002) 9

61. E. M. OOMS, J. G. C. WOLKE, M. T. VAN DE HEUVEL, B. JESCHKE and J. A. JANSEN, Biomaterials 24 (2003) 989

62. "Standard Test Method for Apparent Porosity, Water Absorption, Apparent Specific Gravity and Bulk Density of Burned Refractory Brick and Shapes by Boiling Water," ASTM Designation
C20-92. Annual Book of ASTM Standards, Vol. 15.01 (American Society for Testing and Materials, Philadelphia, PA, 1995), p. 5

63. J. I. WEITZ, B. LESLIE and M. HUDOBA, Circulation 97 (1998) 544

64. E. FERNANDEZ, F. J. GIL, S. M. BEST, M. P. GINEBRA, F. C. M. DRIESSENS and J. A. PLANELL, J. Biomed. Mater. Res. 42 (1998) 403

65. E. FERNANDEZ, F. J. GIL, M. P. GINEBRA, S. M. BEST, F. C. M. DRIESSENS and J. A. PLANELL, J. Mater. Sci. Mater. M. 10 (1999) 169

66. E. FERNANDEZ, F. J. GIL, M. P. GINEBRA, S. M. BEST, F. C. M. DRIESSENS and J. A. PLANELL, J. Mater. Sci. Mater. M. 10 (1999) 223

67. E. J. WHEELER and D. LEWIS, Calcif. Tissue Res. 24 (1977) 243

68. J. L. HOLDEN, J. G. CLEMENT and P. P. PHAKEY, J. Bone Min. Res. 10 (1995) 1400

69. A. BIGI, G. COJAZZI, S. PANZAVOLTA, A. RIPAMONTI, N. ROVERI, M. ROMANELLO, K. SUAREZ and L. MORO, J. Inorg. Biochem. 68 (1997) 45

70. P. Q. RUHE, H. C. KROESE-DEUTMAN, J. G. C. WOLKE, P. H. M. SPAUWEN and J. A. JANSEN, Biomaterials 25 (2004) 2123

71. M. P. GINEBRA, E. FERNANDEZ, F. C. M. DRIESSENS and J. A. PLANELL, J. Am. Ceram. Soc. 82 (1999) 2808

72. A. C. TAS, Biomaterials 21 (2000) 1429

73. A. C. TAS, "Method of Preparing Porous Calcium Phosphate Granules," WIPO-PCT Patent No: WO/03093196, Priority Date: May 06, 2002

74. D. TADIC, F. BECKMANN, K. SCHWARZ and M. EPPLE, Biomaterials 25 (2004) 3335

75. S. TAKAGI and L. C. CHOW, J. Mater. Sci. Mater. M. 12 (2001) 135

76. H. H. K. XU, L. E. CAREY and C. G. SIMON, J. Mater. Sci. Mater. M. 18 (2007) 1345

77. Y. LEE, Y. M. HAHM, S. MATSUYA, M. NAKAGAWA and K. ISHIKAWA, J. Mater. Sci. 42 (2007) 5728

78. L. GUAN and J. E. DAVIES, J. Biomed. Mater. Res. 71A (2004) 480

79. M. BOHNER and F. BAUMGART, Biomaterials 25 (2004) 3569

80. O. MALARD, J. M. BOULER, J. GUICHEUX, D. HEYMANN, P. PILET, C. COQUARD and G. DACULSI, J. Biomed. Mater. Res. 46 (1999) 103

81. V. S. KOMLEV, F. PEYRIN, M. MASTROGIACOMO, A. CEDOLA, A. PAPADIMITROPOULOS, F. RUSTICHELLI and R. CANCEDDA, Tissue Eng. 12 (2006) 3449

82. D. NIKOLIDAKIS, J. VAN DEN DOLDER, J. G. C. WOLKE, P. J. W. STOELINGA and J. A. JANSEN, Tissue Eng. 12 (2006) 2555

83. B. KNEPPER-NICOLAI, A. REINSTORF, I. HOFINGER, K. FLADE, R. WENZ, and W. POMPE, Biomol. Eng. 19 (2002) 227

84. J. P. VOGEL, K. SZALAY, F. GEIGER, M. KRAMER, W. RICHTER and P. KASTEN, Platelets 17 (2006) 462 